\title{
Hubungan IMT (Indeks Massa Tubuh) dengan Ketahanan (Endurance) Kardiorespirasi pada Mahasiswa Pendidikan Dokter Unand 2009-2012
}

\author{
Reny Jayusfani ${ }^{1}$, Afriwardi ${ }^{2}$, Eti Yerizel ${ }^{3}$
}

\begin{abstract}
Abstrak
Saat ini terjadi peningkatan kelebihan berat badan terutama pada generasi muda disebabkan oleh diet yang tidak tepat dan gaya hidup yang tidak aktif. Peningkatan berat badan ini akan berakibat pada penurunan daya tahan kardiorespirasi hingga berdampak pada kapasitas kerja fisik. Tujuan penelitian ini adalah untuk menentukan hubungan Indeks Massa Tubuh (IMT) dengan ketahanan kardiorespirasi pada mahasiswa FK Unand. Penelitian dilakukan pada mahasiswa FK Unand Padang dari Desember 2012 sampai Februari 2013. Studi observasional analitik ini menggunakan desain cross sectional study dengan jumlah subjek 30 orang. Ketahanan kardiorespirasi didapat dengan menghitung nilai $\mathrm{VO}_{2}$ maks menggunakan tes ergometer sepeda metode Astrand 6 minute cycle test. Dilakukan pengukuran berat badan dan tinggi badan. Analisis statistik yang digunakan adalah uji regresi linear sederhana. Hasil penelitian menemukan bahwa rerata IMT 23,2 $\pm 5,1$ dan rerata volume oksigen maksimal 39,5 \pm 12,1. Uji regresi linear menunjukkan terdapat hubungan antara IMT dengan ketahanan kardiorespirasi dengan tingkat hubungan sedang $(r=0,567, p<0,05)$ dengan pengaruh sebesar $32,1 \%\left(R^{2}=0,321\right)$ dan persamaan regresi yang didapat adalah $\mathrm{Y}=70,827-1,349 \mathrm{X}$. Kesimpulan hasil studi ini adalah semakin tinggi indeks massa tubuh semakin rendah ketahanan kardiorespirasi.
\end{abstract}

Kata kunci: volume oksigen maksimal, indeks massa tubuh, ketahanan kardiorespirasi

\section{Abstract}

Nowadays, there are many cases about increasing the weight of body, especially at younger generation. It is caused by anappropriate diet and inactive lifestyle. Increasing of weight will cause declining of cardiorespiratory endurance. So that, it will impact on physical work capacity. The objective of this study was to determine the relationship between cardiorespiratory with Body Mass Index (BMI) in medical student of Andalas University.

The research was done on medical student of Andalas University Padang in December 2012 until February 2012. This research used observational study with cross sectional design study. The subject of this research were 30 people. Cardiorespiratory endurance was obtained by calculate the value of $\mathrm{VO}_{2}$ max. This measurement used ergometer bicycle with the method was using Astrand 6 minute cycle test. This test measured the weight and height body. Statistical analysis was simple linear regression. The result found that the average of BMI is $23.2 \pm 5.1$ and an average maximum oxygen volume is $39.5 \pm 12.1$. Linear regression found that there is a moderate significant effect between $\mathrm{BMI}$ and cardiorespiratory endurance $(r=0.567, \mathrm{p}<0.05)$ with the effect about $32.1 \%\left(R^{2}=0.321\right)$ and the regression equation was $Y=70.827$ to $1.349 \mathrm{X}$.In conclusion, the subjects have average cardiorespiratory endurance level and normal body mass index. If the body of mass index is higher, the cardiorespiratory endurance is lower.

Keywords: maximum oxygen volume, body mass index, cardiorespiratory endurance

Affiliasi penulis : 1. Pendidikan Dokter FK UNAND (Fakultas Kedokteran Universitas Andalas Padang), 2. Bagian Fisiologi FK UNAND, 3. Bagian Biokimia FK UNAND
Korespondensi :Reny Jayusfani, E-mail: fanirj.01@gmail.com, Telp: 085268798804 


\section{PENDAHULUAN}

Manusia yang sehat dan memiliki kesegaran jasmani yang baik akan mampu berprestasi dalam pekerjaan maupun pendidikan sehingga tingkat produktivitas akan meningkat. Daya tahan (endurance) merupakan salah satu unsur dari kesegaran jasmani selain dari kekuatan otot, tenaga ledak otot, kecepatan, ketangkasan, kelenturan, keseimbangan, kecepatan reaksi dan koordinasi. Daya tahan menyatakan keadaan yang menekankan pada kapasitas kerja secara terus-menerus. Hal ini yang banyak dibahas adalah daya tahan kardiorespirasi. ${ }^{1}$

Kardiorespirasi merupakan gabungan dua sistem paru dan kardiovaskular yang bekerja sama dalam fungsi pertukaran dan ditribusi oksigen. Paru sebagai tempat pertukaran oksigen dan karbondioksida antara udara dan darah melalui proses difusi alveoli sedangkan kardiovaskular yang terdiri dari sistem jantung dan pembuluh darah menjalankan fungsi sirkulasi yaitu untuk memenuhi kebutuhan jaringan tubuh, mentranspor oksigen dan zat makanan ke jaringan tubuh, mentranspor produk yang tidak berguna, menghantarkan hormon dari satu bagian ke bagian tubuh lain dan melihara lingkungan yang sesuai didalam cairan tubuh agar sel dapat bertahan hidup dan berfungsi optimal. ${ }^{2}$

Kapasitas tersebut diartikan sebagai kapasitas tubuh untuk menghirup, mengangkut, mengedarkan, membagikan dan menggunakan oksigen $\left(\mathrm{O}_{2}\right)$ sebanyak-banyaknya yang disebut sebagai $\mathrm{VO}_{2}$ maks. $^{3}$ $\mathrm{VO}_{2}$ maks merefleksikan kapasitas kardiorespirasi seseorang dengan semakin banyak oksigen yang dapat ditransportasikan dan dikonsumsi jaringan yang sedang beraktivitas, semakin baik pula ketahanan orang tersebut. Nilai $\mathrm{VO}_{2}$ maks ditentukan oleh fungsi paru, jantung, sel darah merah, dan komposisi tubuh seperti berat badan. Berat badan cenderung berbanding terbalik terhadap $\mathrm{VO}_{2}$ maks. Artinya semakin besar berat badan $(\mathrm{kg})$, semakin rendah $\mathrm{VO}_{2}$ maks. ${ }^{4}$

Kelebihan berat badan berpengaruh terhadap fungsi sistem kardiorespirasi. Kelebihan berat badan tersebut dikaitkan dengan peningkatan jumlah jaringan lemak. Lemak ini meningkatkan jumlah penumpukan plak dalam arteri yang menyebabkan saluran arteri menyempit sehingga meningkatkan resistensi perifer yang berakibat peningkatan tekanan darah dan kerusakan pembuluh darah yang berpengaruh terhadap penurunan kerja sistem kardiorespirasi. ${ }^{5}$

Jaringan lemak ini juga bergantung pada oksigen dan zat makanan dari darah supaya tetap hidup. Makin besar massa tubuh, makin banyak darah yang dibutuhkan untuk memasok oksigen dan makanan ke jaringan tubuh. Ini berarti volume darah yang beredar melalui pembuluh darah menjadi meningkat sehingga memberi tekanan lebih besar pada dinding arteri yang berakibat terjadinya hipertensi. Kelebihan berat badan juga meningkatkan frekuensi denyut jantung dan kadar insulin darah. Peningkatan insulin menyebabkan tubuh menahan natrium dan air yang nantinya akan berakibat peningkatan volume darah. ${ }^{5}$ Sebuah penelitian yang dilakukan Romero et al pada tahun 2007 dengan pasien hipertensi yang diteliti, didapatkan hasil 51,6\% adalah obesitas dan 3,8\% dari obesitas tersebut merupakan obesitas berat; 38,7\% adalah kelebihan berat badan dan hanya $9,7 \%$ memiliki berat badan normal. $^{6}$

Berat badan biasanya dikaitkan dengan Indeks Massa Tubuh (IMT). IMT merupakan penanda kandungan lemak tubuh yang sering digunakan untuk menilai kelebihan berat badan atau obesitas. Menurut WHO seperti yang dikutip Utari (2007), IMT telah dinyatakan sebagai baku pengukuran obesitas pada anak dan remaja usia diatas 2 tahun. ${ }^{7}$ Secara klinis IMT yang bernilai $25-29,9 \mathrm{~kg} / \mathrm{m}^{2}$ disebut overweight dan nilai IMT lebih dari $30 \mathrm{~kg} / \mathrm{m}^{2}$ disebut obese. ${ }^{2}$

Di Indonesia tahun 1995, prevalensi obesitas di 27 provinsi adalah 4,6\%. Pada riset kesehatan dasar tahun 2007 dinyatakan bahwa prevalensi nasional obesitas pada usia lebih dari 15 tahun adalah $10,3 \%{ }^{8}$ Di Sumatera Barat, prevalensi berat badan lebih pada laki-laki $6,2 \%$ sedangkan perempuan $12,3 \%$ dan obesitas pada laki-laki $6,6 \%$ sedangkan perempuan hampir tiga kali lipat yaitu $18,3 \%$ berdasarkan riset kesehatan dasar tahun $2010 .^{9}$

Peningkatan yang cepat terhadap kelebihan berat badan dan obesitas tersebut terutama terjadi pada generasi muda di negara yang berkembang disebabkan oleh diet yang tidak tepat dan gaya hidup 
yang tidak aktif. ${ }^{10}$

Kelebihan berat badan pada mahasiswa akan berakibat terhadap penurunan daya tahan kardiorespirasi yang nantinya akan berdampak pada kapasitas kerja fisik dan penurunan prestasi belajar. Ditambah lagi hubungan antara IMT dengan penurunan ketahanan kardiorespirasi masih diperdebatkan karena terkait adanya faktor determinan lain yang berpengaruh terutama pengeluaran energi dan penyakit-penyakit lain.

Tujuan penelitian ini adalah untuk mengetahui hubungan antara IMT dengan ketahanan (endurance) kardiorespirasi pada mahasiswa Pendidikan Dokter Universitas Andalas.

\section{METODE}

Penelitian dilaksanakan di Laboratorium Fisiologi Fakultas Kedokteran Universitas Andalas pada bulan Desember 2012 - Februari 2013. Subjek penelitian adalah mahasiswa Pendidikan Dokter Unand angkatan 2009-2012. Penelitian dilakukan dengan mengukur berat badan dan tinggi badan serta melakukan tes ergometer sepeda dengan metode Astrand 6 minute cycle test.

Kriteria inklusi adalah mahasiswa Pendidikan Dokter Unand angkatan 2009-2012, berjenis kelamin pria, berusia 17 - 25 tahun, sehat, tidak memenuhi kriteria eksklusi berdasarkan anamnesis dan pemeriksaan fisik dan bersedia mengikuti penelitian ini, serta menandatangani surat persetujuan. Kriteria eksklusi adalah memiliki riwayat penyakit sistem kardiovaskular, memiliki riwayat penyakit paru, menderita anemia, sedang mengonsumsi obat penurun berat badan atau obat penambah hormon, perokok dan mengalami cedera pada kaki.

Metode penelitian yang digunakan adalah observasional analitik dengan desain Cross sectional. Pengambilan subjek dilakukan secara simple random sampling.

Data dianalisis dengan aplikasi computer yang meliputi analisis univariat dan bivariat. Analisis univariat digunakan untuk menggambarkan distribusi frekuensi mahasiswa Pendidikan Dokter Fakultas Kedokteran Universitas Andalas berdasarkan IMT dan ketahanan kardiorespirasi yang dinyatakan dalam bentuk tabel dan narasi. Analisis bivariat digunakan untuk mengetahui hubungan dua variabel tersebut menggunakan uji Regresi Linear dengan persamaan regresi $y=a+b x$.

\section{HASIL}

Tabel 1. distribusi frekuensi responden berdasarkan umur

\begin{tabular}{rrrr}
\hline \multicolumn{2}{c}{ Karakteristik } & $\mathbf{F}$ & $\%$ \\
\hline Umur & & & \\
- & 17 th & 3 & 10,0 \\
- & 18 th & 7 & 23,3 \\
$-\quad 19$ th & 8 & 26,7 \\
$-\quad 20$ th & 7 & 23,3 \\
- & 21 th & 5 & 16,7 \\
\hline Jumlah & & 30 & 100 \\
\hline
\end{tabular}

Berdasarkan Tabel 1 dapat dilihat bahwa dari 30 data responden paling banyak adalah yang berumur 19 tahun yaitu sebanyak 8 orang $(26,7 \%)$.

Tabel 2. Distribusi frekuensi indeks massa tubuh dan volume oksigen maksimal responden penelitian

\begin{tabular}{lccccc}
\hline & F & Mean & SD & Min & Maks \\
\hline IMT & 30 & 23,2 & 5,1 & 17,3 & 38,5 \\
VO2maks & 30 & 39,5 & 12,1 & 23,4 & 71,2
\end{tabular}

IMT = Indeks Massa Tubuh, VO2maks $=$ Volume Oksigen Maksimal, $\mathrm{f}=$ Frekuensi, $\mathrm{SD}=$ Standar Deviasi, Min= Minimal, Maks $=$ Maksimal.

Berdasarkan Tabel 2 dapat dilihat bahwa hasil pengukuran rerata indeks massa tubuh responden adalah 23,2 \pm 5,1 dengan nilai IMT terendah 17,3 dan tertinggi 38,5 . Hasil pengukuran rerata volume oksigen maksimal responden adalah 39,5 $\pm 12,1$ dengan nilai volume oksigen maksimal terendah $23,4 \mathrm{mlO}_{2}{ }^{\prime} \mathrm{kg}^{\prime}$ menit dan tertinggi $71,2 \mathrm{mlO}_{2}^{\prime} \mathrm{kg}^{\prime}$ menit.

Tabel 3. Hubungan indeks massa tubuh dengan ketahanan kardiorespirasi

\begin{tabular}{lccccc}
\hline & \multicolumn{5}{c}{ VO $_{2}$ maks } \\
\cline { 2 - 6 } IMT & $\mathbf{R}$ & $\mathbf{R}^{2}$ & $\mathbf{B}$ & $\mathbf{t}$ & Sig. \\
& .567 & .321 & 70.827 & 8.053 & .001 \\
& & & -1.349 & -3.639 & \\
\hline
\end{tabular}


Berdasarkan Tabel 3 didapat nilai $r=0,567$, artinya terdapat hubungan antara IMT dengan ketahanan kardiorespirasi dengan tingkat hubungan sedang $(0,40-0,599)$. Nilai $R^{2}=0,321$ artinya nilai prediksinya sebesar $32,1 \%$. Dari uji t didapatkan nilai signifikasi sebesar 0,001 ( $p<0,05)$ yang berarti terdapat pengaruh yang signifikan IMT terhadap $\mathrm{VO}_{2}$ maks. Persamaan regresi yang diperoleh adalah $\mathrm{Y}$ $=70,827-1,349 \mathrm{X}$. Dari persamaan tersebut didapatkan bahwa setiap penambahan 1 nilai variabel bebas IMT akan menurunkan nilai variabel terikat $\mathrm{VO}_{2}$ maks sebesar 1,349 .

\section{PEMBAHASAN}

\section{Indeks Massa Tubuh}

Berdasarkan Tabel 2 didapatkan rerata IMT responden adalah 23,2 $\pm 5,1$ dengan nilai IMT terendah 17,3 dan tertinggi 38,5. Dari nilai rerata IMT tersebut, dapat dikatakan bahwa IMT mahasiswa FK Unand masuk dalam kategori normal.

IMT yang normal diperoleh karena adanya aktivitas fisik, tidak merokok, tidak mengonsumsi alkohol dan pilihan makanan sehat. Menghindari sedentary life style juga menjadi faktor yang berhubungan dengan berat badan normal. Selain itu, kegemukan tubuh telah terbukti meningkat dengan penuaan, yang berarti bahwa IMT dapat sesuai dengan kandungan lemak tubuh yang lebih besar pada yang lebih tua dibandingkan dengan yang muda yang cenderung memiliki kandungan lemak tubuh lebih sedikit. ${ }^{11}$

Hal ini sejalan dengan penelitian yang dilakukan oleh Aladawiyyah yang melakukan penelitian terhadap mahasiswa IPB dengan hasil $66,67 \%$ responden termasuk kategori normal. ${ }^{12}$ Hasil yang hampir sama juga didapatkan dari penelitian Otte et al pada tahun 2000 yaitu 23,4 \pm 3,8 yang melakukan penelitian pada mahasiswa. ${ }^{13}$

\section{Volume Oksigen Maksimal}

Berdasarkan Tabel 2 didapatkan rerata volume oksigen maksimal responden adalah 39,5 $\pm 12,1$ dengan nilai volume oksigen maksimal terendah 23,4 $\mathrm{mlO}_{2}{ }^{\prime} \mathrm{kg}$ 'menit dan tertinggi 71,2 $\mathrm{mlO}_{2}^{\prime} \mathrm{kg}^{\prime}$ menit. Dengan melihat hasil yang dicapai oleh subjek dalam pengukuran melelui tes berupa ergocycle tes dari denyut jantung dan merujuk kepada tabel 1 nilai $\mathrm{VO}_{2}$ maks pada laki-laki (nilai dalam $\mathrm{ml} / \mathrm{kg} / \mathrm{min}$ ), maka dapat dikatakan populasi memiliki kondisi kesegaran kardiorespirasi yang rata-rata. Hal ini menunjukan bagaimana efesiensi kerja jantung seseorang dalam populasi tersebut dalam memompakan darah ke seluruh tubuh meskipun kurang memiliki program latihan yang jelas, terencana dan kontinyu.

$\mathrm{VO}_{2}$ maks adalah jumlah oksigen terbesar yang dapat di konsumsi selama latihan maksimal. $\mathrm{VO}_{2}$ maks menggambarkan kemampuan otot untuk mengonsumsi oksigen dalam metabolisme dikombinasikan dengan kemampuan sistem kardiovaskuler dan pernapasan untuk mengantarkan oksigen ke mitokondria otot. Sehingga jika nilai $\mathrm{VO}_{2}$ maks tinggi berarti dapat meningkatkan daya tahan kerja pada aktivitas, yaitu meningkatkan kemampuan rerata kerja lebih besar atau lebih cepat. $^{14}$

Pada penelitian yang dilakukan Subiyono tahun 2007 didapatkan 99,66\% dari seluruh sampel memiliki ketahanan kardiorespirasi tingkat sedang atau ratarata. ${ }^{15}$ Sedangkan pada penelitian Pramadita tahun 2011 didapatkan nilai $\mathrm{VO}_{2}$ maks lebih rendah yaitu $20,30 \pm 1,25 .^{16}$

\section{Hubungan Indeks Massa Tubuh dengan Ketahanan Kardiorespirasi}

Pada Tabel 3 didapatkan bahwa nilai $p<0.05$, artinya terdapat hubungan antara IMT dengan ketahanan kardiorespirasi dengan tingkat hubungan sedang $(r=0,567)$. Dari hasil analisis regeresi linear sederhana didapat nilai $R^{2}=0,321$, artinya IMT mampu menerangkan atau memprediksi nilai $\mathrm{VO}_{2}$ maks sebesar $32,1 \%$. Sisanya sebesar $67,9 \%$ nilai $\mathrm{VO}_{2}$ maks diterangkan oleh faktor lain selain IMT.

Salah satu faktor lain yang mempengaruhi volume oksigen maksimal adalah aktivitas fisik. Orang yang terlatih dapat mentolerir peningkatan metabolisme sekitar 4,5 kali lipat dari daya tahan, yang kemungkinan besar tidak dibatasi oleh sistem transportasi oksigen. Cadangan glikogen yang kosong mungkin menjadi faktor pembatas. Dengan penghematan glikogen, pelatihan menginduksi peningkatan penggunaan asam lemak bebas sebagai substrat untuk otot rangka yang sedang aktif, dan 
waktu kinerja pada $75 \%$ kekuatan aerobik maksimal akan menjadi lebih panjang. ${ }^{17}$

Pada Tabel 3 juga didapatkan persamaan regresi $Y=70,827-1,349 X$ yang artinya bahwa setiap penambahan $1 \mathrm{~kg} / \mathrm{m}^{2}$ IMT akan menurunkan volume oksigen maksimal sebesar $1,349 \mathrm{mlO}_{2} / \mathrm{kg} /$ menit.

ketahanan kardiorespirasi merupakan kemampuan melepaskan energi metabolisme yang ditunjukkan dengan kemapuan kerja tubuh relatif untuk menghasilkan efisiensi dari pembuluh darah, jantung dan paru dalam periode waktu lama dengan menggambarkan kemampuan otot untuk mengonsumsi oksigen dalam metabolisme. ${ }^{14}$ Sehingga dengan adanya obesitas secara tidak langsung mempengaruhi ketahanan kardiorespirasi yang dinilai dengan $\mathrm{VO}_{2}$ maks.

Penelitian yang dilakukan oleh Kristant tahun 1995 didapatkan juga hasil bahwa IMT berpengaruh terhadap $\mathrm{VO}_{2}$ maks. Setiap kenaikan 1 $\mathrm{kg} / \mathrm{m}^{2} \mathrm{IMT}$, diikuti dengan penurunan $\mathrm{VO}_{2}$ maks sebesar $1,00 \mathrm{ml} / \mathrm{kg} /$ menit atau terjadi penurunan nilai $\mathrm{VO}_{2}$ maks sebesar $10 \mathrm{ml} /$ menit untuk setiap kelebihan berat badan $10 \mathrm{~kg} .^{18}$ Pada penelitian yang dilakukan Utari tahun 2007 juga didapatkan hubungan antara IMT dengan ketahanan kardiorespirasi yang menunjukkan bahwa semakin tinggi IMT semakin rendah tingkat ketahanan kardiorespirasinya $(r=$ $0,697 ; p=0,000)^{7}$

\section{KESIMPULAN}

Rerata indeks massa tubuh pada responden termasuk kategori normal. Rerata $\mathrm{VO}_{2}$ maks responden termasuk kategori rata-rata, baik untuk usia 13-19 tahun dan usia 20-29.

Ada hubungan tingkat sedang antara indeks massa tubuh dengan ketahanan (endurance) kardiorespirasi dengan nilai $r=0,567$ ( $p$ value $<0,05$ ) dan besar prediksi $=32,1 \%$.

\section{DAFTAR PUSTAKA}

1. Susilowati. Faktor-faktor risiko yang berpengaruh terhadap kesegaran jasmani polisi lalu lintas di kota Semarang (tesis). Semarang: Fakultas Kesehatan Masyarakat Universitas Diponegoro; 2007. (diunduh 7 februari 2011). Tersedia dari:
URL: HYPERLINK http://eprints.undip.ac.id/ 5268/1/Susilowati.pdf

2. Guyton AC, Hall JE. Buku ajar fisiologi kedokteran. Edisi ke- 11. Jakarta: EGC; 2008.

3. Kusnanik NW. Perbandingan antropometri dan biomotorik pada tiga stadia siklus menstruasi anggota unit kegiatan mahasiswa bidang olahraga Universitas Negeri Surabaya. Kemas. 2007;2(2):152-61.

4. Uliyandari A. Pengaruh latihan fisik terprogram terhadap perubahan nilai konsumsi oksigen maksimal $\left(\mathrm{VO}_{2} \max \right)$ pada siswi sekolah bola voli tugu muda Semarang usia 11-13 tahun (skripsi). Semarang: Fakultas Kedokteran Universitas Diponegoro; 2009. (diunduh 7 Februari 2011). Tersedia dari: URL: HYPERLINK http://eprints. undip.ac.id/8090/1/Adhikarma Uliyandari.Pdf

5. Sneps SG. Mayo clinic hipertensi, mengatasi tekanan darah tinggi. Jakarta: Intisari Mediatama; 2005.

6. Romero R, Bonet J, Sierra ADL, Aguilera MT. Undiagnosed obesity in hypertension: clinical and therapeutic implication. Blood Pressure. 2007;16: 347-53.

7. Utari A. Hubungan indeks massa tubuh dengan tingkat kesegaran jasmani pada anak usia 12-14 tahun (tesis). Semarang: Fakultas Kedokteran Universitas Diponegoro; 2007. (diunduh 3 November 2011). Tersedia dari: URL: HYPERLINK http://eprints.undip.ac.id/16285/1/AGUSTINI UTA $\underline{\text { RI.pdf }}$

8. Kementerian Kesehatan RI. Laporan nasional riset kesehatan dasar 2007. Jakarta: Balitbangkes Depkes RI; 2008. (diunduh 20 November 2011). Tersedia dari: URL: HYPERLINK http://www. depkes.go.id

9. Kementerian Kesehatan RI. Riset kesehatan dasar 2010. Jakarta: Balitbangkes Depkes RI; 2010.

10. Nisar N, Qadri MH, Fatima K, Perveen S. Dietary habits and life style among the students of a private medical university Karachi. J Pak Med Assoc. 2008; 58:687-90.

11. Koski ML. Body mass index and obesity among adults in Finland. Finland: Helsinki; 2001.

12. Aladawiyyah R. Analisis hubungan antara 
kecukupan gizi dan status gizi dengan tingkat kebugaran mahasiswa IPB (skripsi). Bogor: Fakultas Ekologi Manusia IPB; 2012. (diunduh 27 Februari 2013). Tersedia dari: URL: HYPERLINK http://repository.ipb.ac.id/handle/123456789/56245

13. Otte A, Hassler J, Brogowski J, Bowen JC, Mayhew JL. Relationship between body mass index and predicted \% fat in college men and women. Mo J Health, Physical Education, Recreation and Dance. 2000;10:23-9.

14. Adiwinanto W. Pengaruh intervensi olahraga di sekolah terhadap indeks massa tubuh dan tingkat kesegaran kardiorespirasi pada remaja obesitas (tesis). Semarang: Fakultas Kedokteran Universitas Diponegoro; 2008. (diunduh 4 Maret 2013). Tersedia dari: URL: HYPERLINK http://eprints.undip.ac.id/28849/1/Wahyu Adiwinan to Tesis.pdf
15. Subiyono HS. Tingkat kesegaran jasmani daya tahan kardiorespiratori penderita gangguan jiwa pasien rumah sakit jiwa Dr. Amino Gondohutomo, Pedurungan, Semarang. KEMAS. 2007;3(1):69-79.

16. Pramadita A. Hubungan indeks massa tubuh dengan kesegaran kardiovaskular yang diukur dengan harvard step test dan $20 \mathrm{~m}$ shuttle run test pada anak obesitas (skripsi). Semarang: Fakultas Kedokteran Universitas Diponegoro; 2011. (diunduh dari 27 Februari 2013). Tersedia dari: URL: HYPERLINK http://eprints.undip.ac.id/32875/ 1/Arjatya P.pdf

17. Astrand PO. Physical activity and fitness. Am J Clin Nutr. 1992; 55:1231S-6S.

18. Kristanti CM. Faktor-faktor yang mempengaruhi kesegaran jasmani pelajar SLTA di Jakarta. Cermin Dunia Kedokteran. 1995;102:24-7. 